\title{
On an electrode producing massive quantities of tritium and helium
}

\author{
Chun-Ching Chien *, Dalibor Hodko **, Zoran Minevski and John O’M. Bockris
}

Chemistry Department, Texas A\&M University, College Station, TX 77843-3255 (USA)

(Received 2 January 1992; in revised form 22 April 1992)

* Permanent address: Chemistry Division. Institute of Nuclear Energy Research. P.O. Box 3-6 Lung-Tan. Taiwan. Republic of China.

** On leave from Rudjer Boskovic Institute, P.O.B. 1016. 41000 Zagreb. Croatia.

\begin{abstract}
A Pd electrode has been examined which produced a concentration of tritium in a 0.1 M LiOD solution around $10^{3}$ times above background. Tritium production at a given potential ceased after a few days, but could be restarted by a small increase of the deuterium overpotential. Correspondingly, $\mathrm{He}^{4}$ was found in 9-10 pieces of the Pd electrode at 2-100 times background. Addition of fresh amounts of $\mathrm{D}_{2} \mathrm{O}$ quenched the $\mathrm{T}$ production which began again spontaneously after 1-2 days. If the T had come from contamination, ${ }^{3} \mathrm{He}$ would have been found in the electrode: it was absent. Loss of charge by the nucleus lakes place when the fugacity of D in voids exceeds $10^{17} \mathrm{~atm}$ (Lifshitz and Pitaevskii, 1963). Sporadicity of function arises from the state of the surface, which is difficult to reproduce. The surface state controls the mechanism of $\mathrm{D}^{-}$evolution: only some mechanisms give a fugacity high enough to cause fusion. Only one electrode out of four examined produced $\mathrm{T}$ and ${ }^{4} \mathrm{He}$. The surface of this electrode contained a $\mathrm{Cu}$-mosaic structure, not seen on the inactive electrodes.
\end{abstract}

\section{INTRODUCTION}

Since March 1989, groups in many countries have been active in carrying out experiments on Cold Fusion. There are (Feb. 1992) around 380 published papers and reports from Government Institutes which give accounts of positive observations on Cold Fusion (e.g. reviews in refs. 1-4). Thus, there is evidence for the production (after some hundreds of hours) of excess heat in the region of $10-30 \%\left(0.5-100 \mathrm{~W} \mathrm{~cm}^{-3}\right.$, with reports up to $\left.1 \mathrm{~kW} \mathrm{~cm}{ }^{-3}\right)$; neutrons in the range $1-10 \mathrm{n} \mathrm{s}^{-1} \mathrm{~cm}^{-2}$ with occasional reports of $10^{6} \mathrm{n} \mathrm{s}^{-1} \mathrm{~cm}^{-2}$ in bursts; tritium, several times above background with $20 \%$ of the reports amounting to $10^{-3}-10^{-5}$ above background; helium in the electrode at up to 100 times background. Gamma and X-ray emission have also been reported. ${ }^{5}$

The successes are accompanied by considerable difficulties. 
(1) The phenomena, when they are seen, are associated with an initiation time of several hundreds of hours.

(2) Even so, the majority of attempts fail to manifest anomalous phenomena at all.

It would be desirable to make simultaneous measurements of heat, neutrons, tritium, helium, X-rays and gamma rays. Economic considerations have made it necessary to measure one or two of these quantities. Thus, the most obvious and direct proof of fusion is the production of tritium from deuterium and we have gone principally in this direction. ${ }^{4}$

More than 40 reports exist from different groups concerning the formation of $\mathrm{T}$ above the enrichment. ${ }^{2}$

We have recently observed an electrode that yielded $\mathrm{T}$ at $\sim 10^{4}$ times above background. Production of tritium continued for three weeks and was intentionally interrupted.

\section{EXPERIMENTAL}

\section{Experimental cell}

The cell (Fig. 1) could contain $80 \mathrm{~cm}^{3}$ of solution, and possessed a Teflon cap in which there were three small holes for the emission of gases. The glass was conventional borosilicate glass. It was washed several times in distilled water before use.

\section{Temperature control}

The average temperature value varied between approx. 21 and $23^{\circ} \mathrm{C}$.

\section{Electrical}

The total potential applied to the cell was controlled and measured by a dc power supply (BK Precision, Model 1635, Maxtec International Co. (Chicago, ID). The cell potential, Pd electrode potential and current were measured by using Digital Multimeters (Keithley, Model 616) and continuously monitored on XY-t recorders (Houston Instruments, Models 100 and 200).

\section{Electrodes}

Pt wire (99.95\%), $0.5 \mathrm{~mm}$ in diameter, $100 \mathrm{~cm}$ in length, was used as the anode. A saturated calomel electrode (Radiometer, K401) served as a reference electrode. The HaberLuggin capillary used a $0.5-1 \mathrm{~mm}$ working distance. Electrode potentials were obtained in a secondary way from a simulated experiment in a dummy cell in which electrode potentials were measured under the same conditions. 


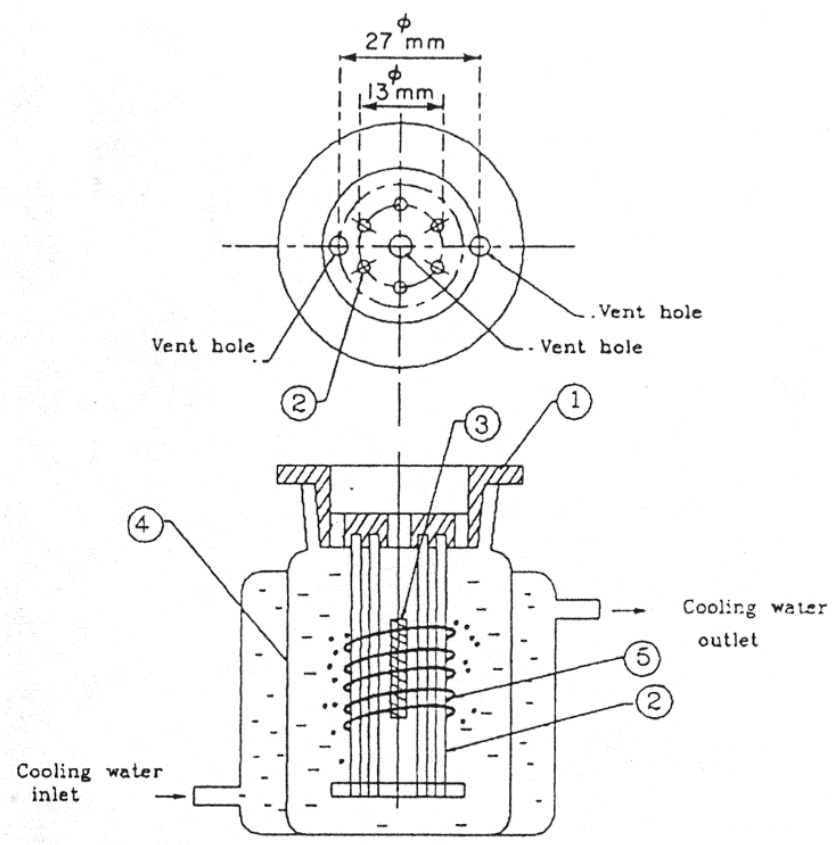

Fig. 1. Scheme of the electrolysis cell. (1) Teflon cap: (2) glass rod: (3) Pd rod; (4) glass beaker; (5) Pt coil.

The palladium electrode was $1.6 \mathrm{~cm}$ in length and $1 \mathrm{~cm}$ in diameter $(99.99 \% \mathrm{Pd})$. All electrodes investigated were fabricated from palladium purchased from Elecmat Co. (Plainfield, NJ, USA). Palladium rods were made by melting the palladium ingot at about $1700^{\circ} \mathrm{C}$ under a nitrogen atmosphere, then casting in a high-temperature resistant ceramic shell, and shaping into rods. Palladium was obtained from original bullion and not refined from scrap ${ }^{6}$. The distance between the working and counter electrodes was approx. $2 \mathrm{~mm}$, and yielded an electrolyte resistance of about $10 \Omega$

The palladium electrodes were pretreated by acid etching and then electro-chemically in the following way.

(1) Acid etching. The Pd rod was immersed in dilute nitric acid solution (1.3-1.6 M) for $50 \mathrm{~h}$ or until the Pd surface lost its lustre. The electrode was washed with triply distilled water and silver soldered to a $\mathrm{Cu}$ wire contact (Fig. 2). It was acid etched (for another day) and the washing procedure repeated. The $\mathrm{Cu}$ wire was not brought into contact with the etching solution. Residual acid was washed off with distilled water and the electrode stored in a reservoir of distilled water above the $\mathrm{Cu}$ wire for about 2 weeks. "

\footnotetext{
* There was contact between the solution and copper when the electrode was resting in distilled water. XPS measurement showed $\mathrm{Cu}$ on the electrode.
} 


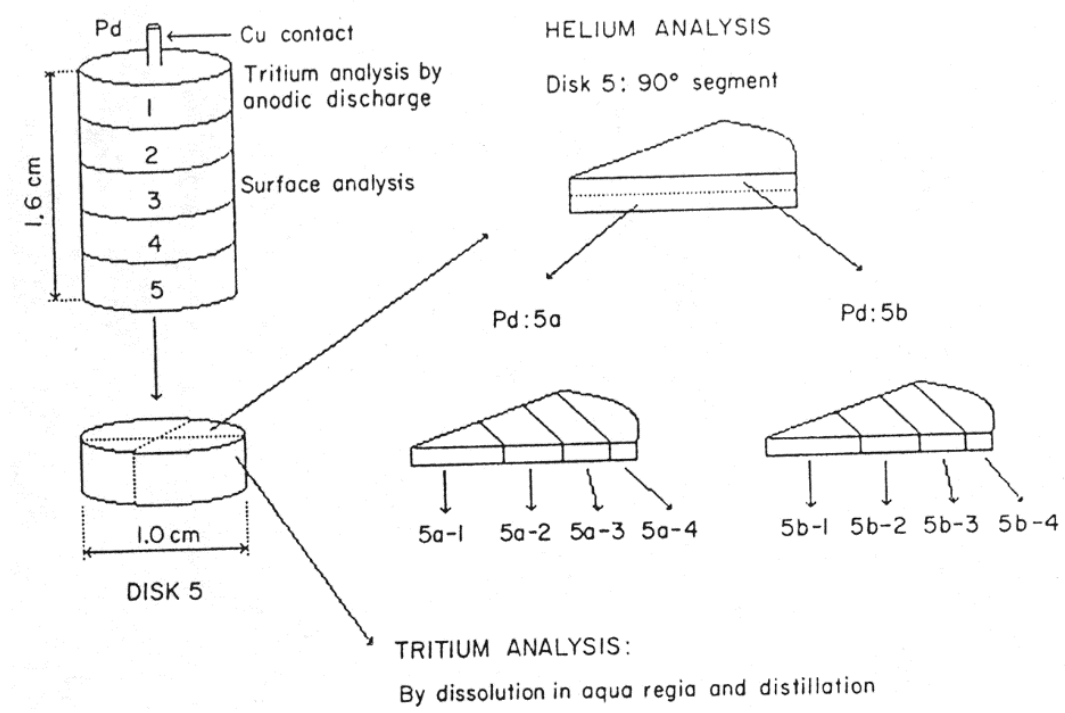

Fig. 2. Pd electrode which produced tritium: cutting diagram and annotation of samples used in subsequent analysis.

(2) Anodic treatment. The acid-treated Pd rod was mounted in the electrolysis cell and 0.1 M LiOD solution introduced to fill the cell to the top of the Pd rod, again avoiding contact between $\mathrm{Cu}$ and the solution. Anodic treatment consisted of applying a positive electrode potential of $2.0 \mathrm{~V}$ for $2 \mathrm{~h}$, then the potential was raised to $2.3 \mathrm{~V}$ for $30 \mathrm{~min}$. After this pretreatment, electrolyte $(0.1 \mathrm{M} \mathrm{LiOD})$ was added up to the volume of $80 \mathrm{ml}$ and the Pd rod was used in $\mathrm{D}_{2} \mathrm{O}$ electrolysis.

\section{Materials}

$\mathrm{D}_{2} \mathrm{O}$ was from Isotech Inc., Matheson, with a low tritium background of 12-18 DPM $\mathrm{ml}^{-1}$. Its original $\mathrm{H}_{2} \mathrm{O}$ content was $0.1 \%$. $0.1 \mathrm{M} \mathrm{LiOD}$ electrolyte was prepared by dissolving Li metal (Johnson \& Matthey, $0.38 \mathrm{~mm}$ thick Li foil, 99.95\%).

The liquid scintillation cocktail (LSC) was Bio-safe II from Research International Product Co. (Mount Prospect, IL). The tritium background of $6.5 \mathrm{ml}$ of scintillation cocktail, normally used for T analysis, was $26+3 \mathrm{DPM} \mathrm{ml}^{-1}$. 


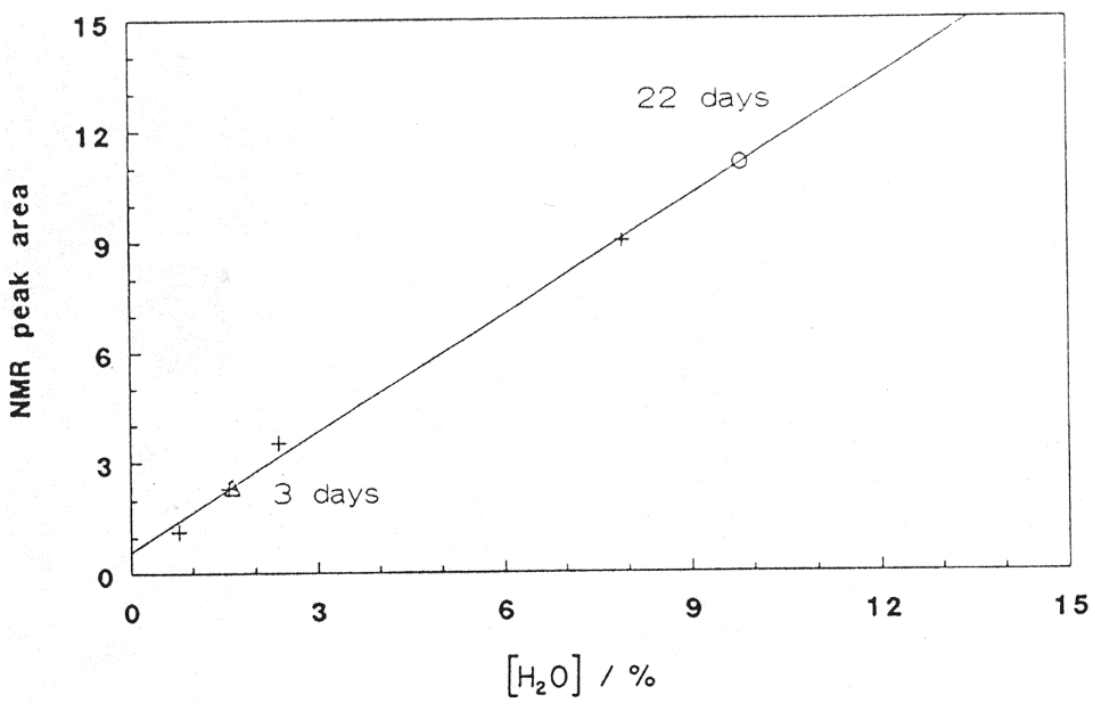

Fig. 3. NMR light water determination at different stages of electrolysis. (+ ) $0.1 \mathrm{M} \mathrm{LiOD}$ calibration: $(\Delta)$ after 3 days of electrolysis; (O) after 22 days. 


\section{Light water content in $\mathrm{D}_{2} \mathrm{O}$}

The open design of the cell allowed $\mathrm{H}_{2} \mathrm{O}$ from the atmosphere to enter the cell through the vent holes. Therefore the $\mathrm{H}_{2} \mathrm{O}$ content in the electrolyte was checked by using NMR spectroscopy (NMR spectrometer, Model XL200E). Sample preparation was done in a glove box under an argon atmosphere. Standard samples were sealed in NMR tubes and calibration repeated each time the sample was measured.

The straight line (Fig. 3) is the calibration curve (obtained versus prepared standards) and two points on the graph represent the $\mathrm{H}_{2} \mathrm{O}$ content at different times of electrolysis. The first point $(\Delta)$ shows $1.6 \% \mathrm{H}_{2} \mathrm{O}$ content after only 3 days of electrolysis. The $\mathrm{H}_{2} \mathrm{O}$ content increased up to $9.8 \%$ (second point, $\mathrm{O}$ ) after 22 days of electrolysis.

\section{Cutting the palladium specimen for ${ }^{3} \mathrm{He},{ }^{4} \mathrm{He}$ and surface analysis}

After the electrolysis was stopped intentionally a Pd electrode which produced tritium was transferred into liquid $\mathrm{N}_{2}$ (1-2 s). The electrode was kept in liquid $\mathrm{N}$, for one week. Then it was removed and cut into five pieces for further analysis. A rotary cutter was used. The cutting operation was performed quickly, the time the Pd was out of liquid N, was less than 1 min, the Pd rod remaining well below room temperature. Figure 2 shows how the Pd electrode was cut and the position of cut discs used for surface analysis and for ${ }^{3} \mathrm{He}$ and ${ }^{4} \mathrm{He}$ analysis. The first piece (No. 1 in Fig. 2) with the $\mathrm{Cu}$ contact attached was used in an anodic dissolution experiment. The second and fourth, (Nos. 2 and 4, Fig. 2) sections were preserved in liquid $\mathrm{N}_{2}$, for further analysis. Disc No. 3 was used for surface analysis. Disc No. 5 was cut for ${ }^{3} \mathrm{He}$ and ${ }^{4} \mathrm{He}$ analysis. Two $90^{\circ}$ segments from disk No. 5 were cut further (as shown in Fig. 2 for one of the $90^{\circ}$ segments) into smaller pieces of approx. $30 \mathrm{mg}$, and analyzed for ${ }^{3} \mathrm{He}$ and ${ }^{4} \mathrm{He}$.

\section{XPS and EDS surface analysis}

XPS and EDS analyses were performed on palladium disc-shaped samples. A first set of samples was cut from the electrode from cell B (Fig. 2). A second set was from the same original source and was not preserved in liquid $\mathrm{N}_{2}$. It consisted of samples that were pretreated only chemically in the same way as those from cell $\mathrm{B}$. The third set consisted of samples which had been electrolyzed and had not given tritium. The fourth set of samples was from the original source and represented a virgin Pd sample, with no pretreatment.

All palladium samples were allowed to remain under high vacuum in an Edwards Coating System E306A for $24 \mathrm{~h}$ at pressures lower than $5 \times 10^{-6}$ Torr prior to analysis to avoid outgassing during the measurement.

\section{XPS analysis}

XPS was carried out using a Perkin-Elmer 5500 photoelectron spectrometer. The system was equipped with a dual anode (Mg and AD X-ray source and operated at $10^{-9}$ Torr. The XPS spectra were taken applying $\mathrm{Mg} K(h v=1253.6 \mathrm{eV})$ irradiation, with an angle 
of incidence of $45^{\circ}$, as the photon source $(300 \mathrm{~W}, 15 \mathrm{kV})$.

To obtain a depth profile, the palladium surface was sputtered by Ar ion bombardment and spectra were collected in the center of the etched area. XPS analysis was performed alternately with sputtering. During sputtering the pressure of the argon ion gas was $4.5 \times 10^{-8}$ Torr, the emission current of the ion gun was $25 \mathrm{~mA}$, and ion gun voltage $3 \mathrm{kV}$.

\section{EDS analysis}

A JEOL JSM-6400 SEM equipped with a Tracor Northon (NORAN) 1-2 (EDS/Image processing) system with the atmospheric thin window which allows detection of light elements down to boron was used to analyze the bulk of the palladium electrode to a depth of $1 \mu \mathrm{m}$. The voltage used was $25 \mathrm{kV}$ with an angle of incidence of $34^{\circ} \mathrm{C}$. EDS conditions were the same for all regions analyzed with the $100 \mathrm{~s}$ count time.

Compositions were calculated by use of a built-in standard analysis program including sensitivity corrections for each element.

\section{Helium analysis}

Palladium samples which had shown tritium production, platinum anode samples and non-electrolyzed Pd electrode samples were sent, packed in solid $\mathrm{CO}_{2}$, to Rockwell International, Los Angeles, CA, for ${ }^{3} \mathrm{He}$ and ${ }^{4} \mathrm{He}$ analysis by mass spectrometry. Cut palladium discs (Fig. 2) were kept in liquid $\mathrm{N}_{2}$ for 16 days (samples of series $5 \mathrm{a}$ and $5 \mathrm{~b}$ ) and 66 days (samples of series 5c), respectively, before sending them for ${ }^{3} \mathrm{He}$ and ${ }^{4} \mathrm{He}$ analysis. The $90^{\circ}$ disc segments were further cut into smaller pieces of about $30 \mathrm{mg}$. Samples $5 \mathrm{c}$ were cut in the same way as shown for samples $5 \mathrm{a}$ and $5 \mathrm{~b}$, but from another $90^{\circ}$ segment (Fig. 2). The helium content was determined following vaporization in a resistance-heated tungsten-wire crucible in one of the mass spectrometer system's high-temperature vacuum furnaces ${ }^{7}$. Details of the calibration procedures, determination of the background helium release from the system, including hot and cold blank tests, analysis of the Rockwell Control Pd specimens, as well as virgin Pd and Pt anode samples will be published separately ${ }^{8}$. It was observed, despite three $\mathrm{Zr}-\mathrm{Al}$ alloy hydrogen getters in the system, that enough deuterium (from a fully charged $\mathrm{Pd}$ electrode) made its way into the mass spectrometer to produce a HD artifact which interfered with the signal for ${ }^{3} \mathrm{He}^{8}$. In the case of ${ }^{4} \mathrm{He}$ such interference does not occur because of better resolution between ${ }^{4} \mathrm{He}$ and hydrogen isotope signals. Samples $5 \mathrm{~b}$ and $5 \mathrm{c}$ were thus pretreated thermally by baking in a vacuum oven $\left(<10^{-4}\right.$ Torr $)$ at $\sim 150^{\circ} \mathrm{C}$ for $24 \mathrm{~h}$ prior to analysis. In this way the mass spectra collected were free from any interference of residual hydrogen isotopes.

\section{Tritium analysis}

Samples were taken about one to two times per day, each sample being $0.5 \mathrm{ml}$ syringed by a micropipet. Disposable Eppendorf flex tips (Brinkmann Instruments, Inc. New York) of $0.1 \mathrm{ml}$ were used for sampling. 
Two amounts of fresh $\mathrm{D}_{2} \mathrm{O}$ (see above) were added to the cell, one $14 \mathrm{ml}$ (at $148 \mathrm{~h}$ of electrolysis) and the other $30 \mathrm{ml}$ (at $406 \mathrm{~h}$ of electrolysis). The $0.5 \mathrm{ml}$ sample was added to a vial and then $6.5 \mathrm{ml}$ of the Biosafe cocktail $(26+3$ DPM) made up the basic measuring vial. This was kept in darkness for $3 \mathrm{~h}$ and measured for $10 \mathrm{~min}$ in a Wallac LKB 1410 liquid scintillation counter.

The natural decline of the radiation was about $0.5 \%$ per month.

The liquid scintillation counter was equipped with a chemiluminescence counter and indicated its own efficiency.

The calculation of the tritium content was made in the following way:

$\mathrm{DPM} \mathrm{m} \mathrm{m}^{-1}=\left(\mathrm{CPM} / \mathrm{ml}_{\text {sample }}-\mathrm{CPM}_{\text {cocktail }}\right) \times(V / E)$

where $E$ is the efficiency of the detector and $\mathrm{V}$ is a volume factor to give results per $\mathrm{ml}$ of sample.

Errors

The counting errors were as follows. At low count rates, and with $10 \mathrm{~min}$ counting, the random errors in counting were up to $10 \%$, whilst at high count rates $(\sim 20000 \mathrm{DPM} / \mathrm{ml})$, this figure dropped to less than $2 \%$. Samples of low count rates (approx. $35 \mathrm{DPM} / \mathrm{ml}$ ) showed $38 \%, 9.9 \%$ and $2.8 \%$ relative standard deviation error for 1,10 and 60 min of counting time, respectively. Ten minute analyses were usually performed. 

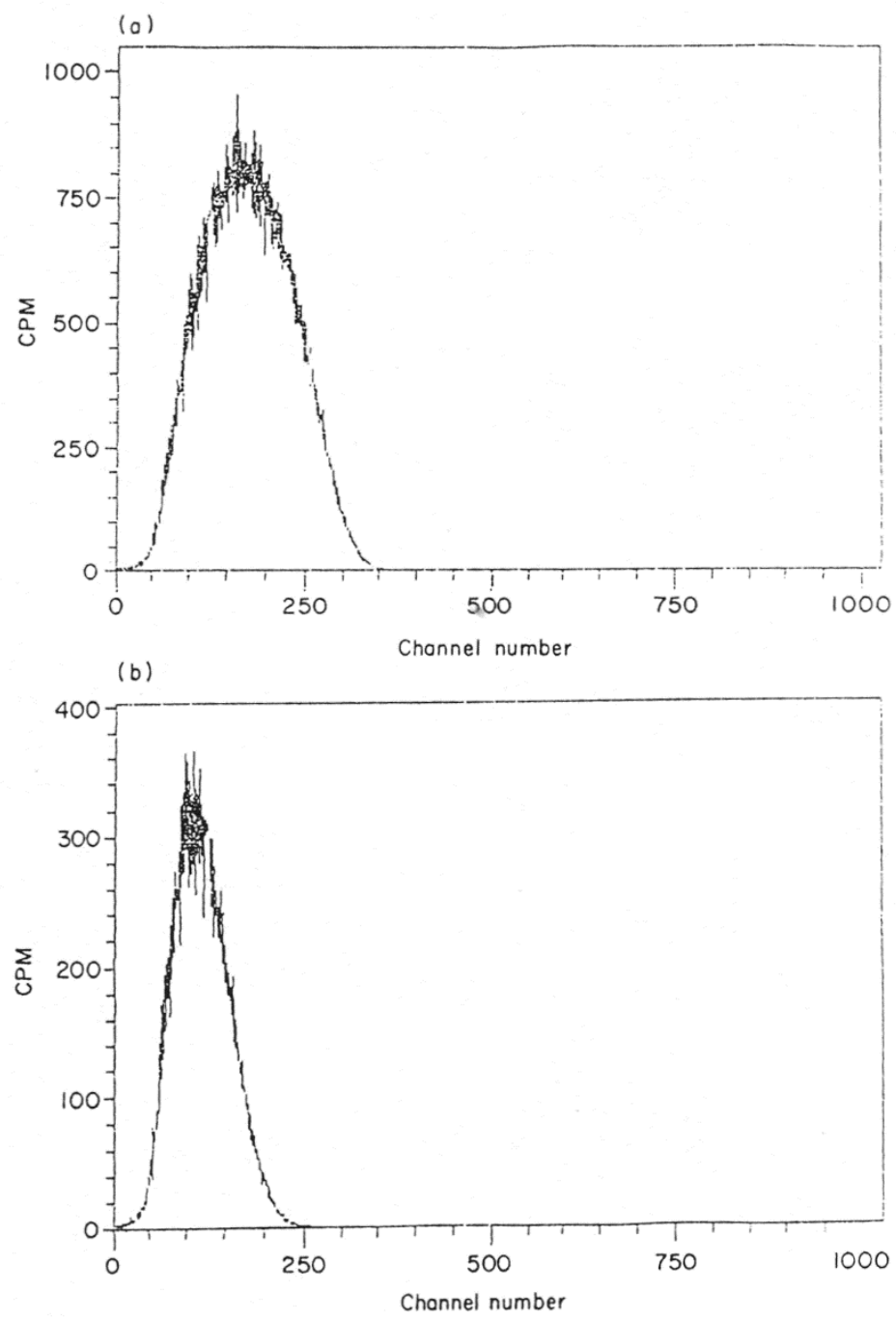

Fig. 4. Tritium energy spectra of: (a) standard tritium aqueous solution, (b) tritium sample taken at the end of electrolysis. 
A detailed analysis of the sample energy spectra yielded the correct beta energy end point for tritium when compared with a standard tritium sample. Figure 4(a) shows a standard tritium spectrum (activity 200000 DPM) and Fig. 4(b) a T sample taken before the electrolysis was stopped. Both spectra exhibit the same pattern with maxima within the same energy range or at the same corresponding channel numbers (130-150).

The tritium background of the scintillation cocktail was determined as $26 \pm 3$ DPM. A typical value for $\mathrm{D}_{2} \mathrm{O}$ (Isotech Inc.) was 32-35 DPM/0.5 ml (or, as background corrected value, $12-18 \mathrm{DPM} / \mathrm{ml}$ ). When the tritium samples showed a counting activity several orders of magnitude higher than the background value, a background correction was not taken into consideration. Positive tritium findings were measured independently on a Wallac 1210 liquid scintillation counter, in the laboratory of Prof. M. McLaine (Department of Nuclear Engineering, Texas A\&M University).

\section{RESULTS}

\section{Tritium analysis}

Tritium measurements before the start of electrolysis

After careful Pd acid etching pretreatment and storing in distilled water, anodic pretreatment was performed in an $80 \mathrm{ml}$ cell, filled up with $0.1 \mathrm{M} \mathrm{LiOD}$, at $2.1 \mathrm{~V}$ for $2 \mathrm{~h}$ and at $2.3 \mathrm{~V}$ for $0.5 \mathrm{~h}$. Results are shown in Table 1.

No increase in $\mathrm{T}$ activity was observed in the electrolyte after anodic pretreatment (Table 1). A high potential (2.3 V), although applied for $0.5-2 \mathrm{~h}$, should cause tritium contaminants to be expelled from the electrode. No significant increase was seen.

\section{Initiation period and commencement of tritium activity}

After anodic treatment, charging was started at $-0.05 \mathrm{~V}$ (vs. RHE) in the negative direction. No increase in tritium activity was observed (Fig. 5). After $35 \mathrm{~h}$, the cathode potential was decreased to $-0.10 \mathrm{~V}$. This decrease in cathode potential triggers the reaction and a steady increase in tritium activity was observed after that. The initial, almost linear, relationship between tritium activity and time, is in Fig. 5, which presents results of two cells (A and B), run in parallel. One (cell B) out of four cells showed high tritium level production.

\section{TABLE 1}

Typical tritium activity analysis of the $0.1 \mathrm{M}$ LiOD electrolyte before and after anodic pretreatment

\begin{tabular}{ll}
\hline $\begin{array}{l}\text { T activity before anodic pretreatment } \\
\text { /DPMmr }\end{array}$ & $\begin{array}{l}\text { T activity after anodic pretreatment } \\
/ \text { DPM mr}^{1}\end{array}$ \\
\hline $12 \pm 3$ & $12 \pm 3$ \\
\hline
\end{tabular}




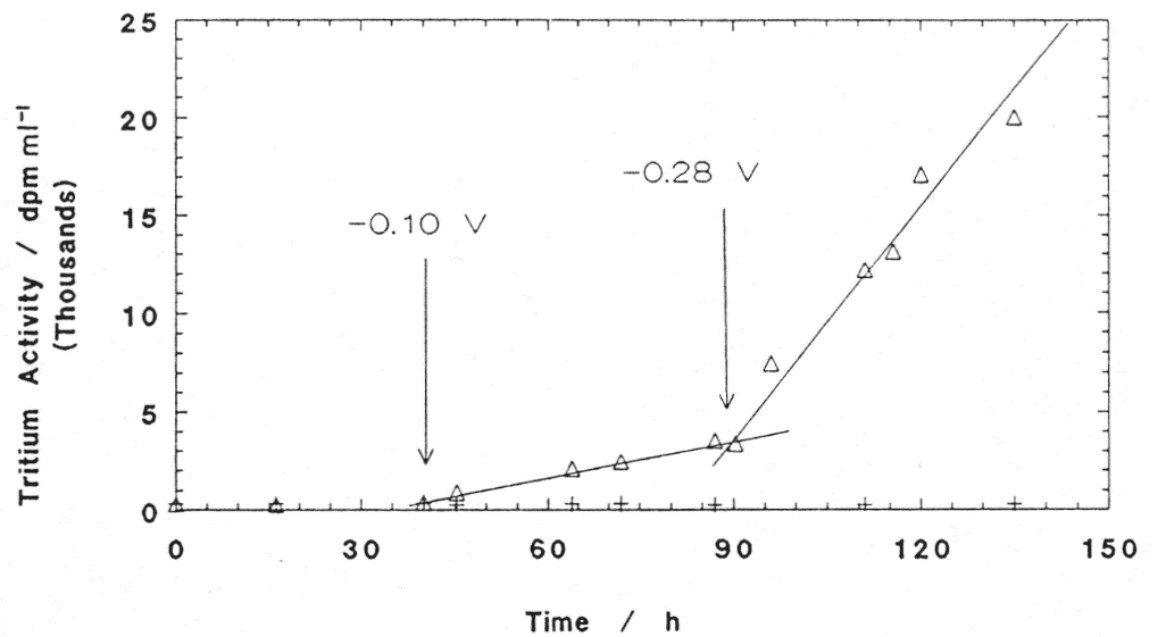

Fig. 5. Tritium activity measurements vs. time at the initial stage of electrolysis: $(+)$ cell A, which showed no tritium in excess; $(\Delta)$ cell $\mathrm{B}$, which showed high levels of tritium production. Numbers indicate cathode potentials vs. RHE.

The maintenance of a continuous increase in tritium activity, triggered by small increases in applied potential, seems not to have been recorded previously. In previous observations of T activity, tritium has appeared in a burst-like manner. ${ }^{9}$

Rate of tritium production (Figs. 5 and 6)

When the cathode potential was in the range -0.05 to $-0.10 \mathrm{~V}$ the rate was $\sim 2.1 \times 10^{6}$ $\mathrm{T}$ atoms s $\mathrm{sm}^{-2}$. When the potential was decreased to $-0.28 \mathrm{~V}$, the rate of production became $1.7 \times 10^{7} \mathrm{~T}^{-2} \mathrm{atom} \mathrm{s}^{-1} \mathrm{~cm}^{-2}$. After lowering the potential to $-0.44 \mathrm{~V}$ the tritium production rate increased $\left(8.1 \times 10^{6} \mathrm{~T}_{\text {atoms s}}{ }^{-1} \mathrm{~cm}^{-2}\right)$. The tritium production reached its maximum of 3.8 $\times 10^{7} \mathrm{~T}$ atoms s${ }^{-1} \mathrm{~cm}^{-2}$ at $327 \mathrm{~h}$ of electrolysis. The reaction was quenched at $406 \mathrm{~h}$, when D:O was added. Tritium production restarted again at $471 \mathrm{~h}$ of electrolysis with no potential increase. The tritium production rate observed was $2 \times 10^{7} \mathrm{~T}_{\text {atoms s}}{ }^{-1} \mathrm{~cm}^{-2}$. 


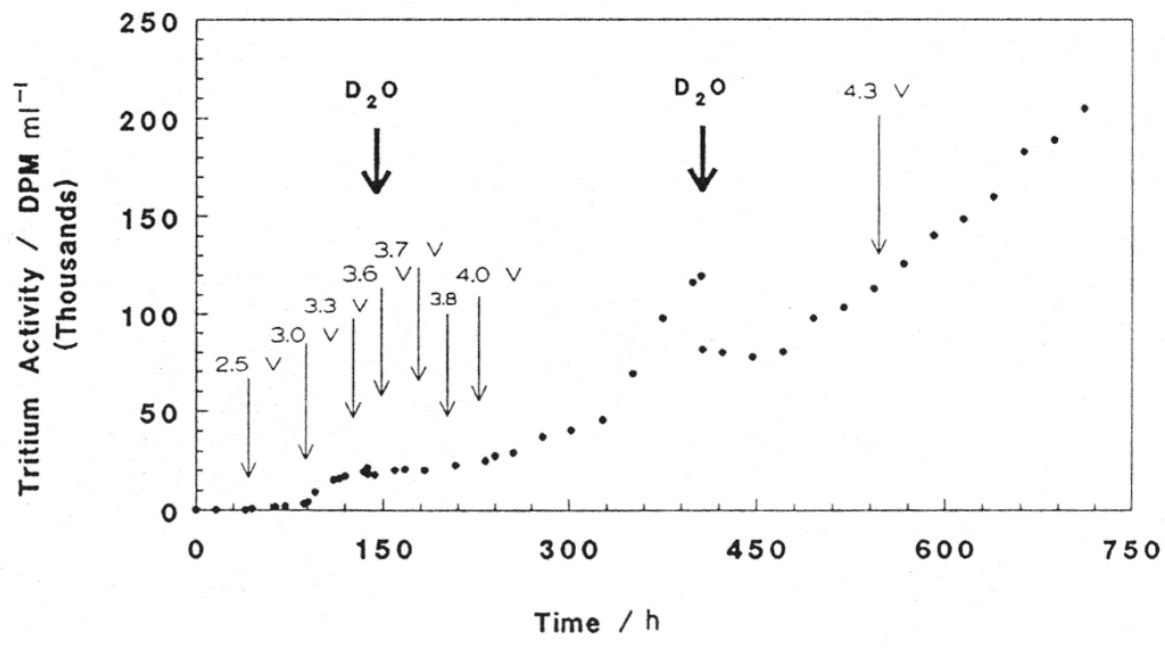

Fig. 6. Recording of the tritium events during one month of continuous tritium production in cell B Arrows indicate voltage adjustment. Numbers indicate cathode potentials vs. RHE.

\section{Quenching of tritium production}

After the addition of make up heavy water $\left(14 \mathrm{~cm}^{3}\right.$ added at $\left.138 \mathrm{~h}\right)$, tritium production ceased for 2 days. The electrode potential was increased several times to trigger the reaction again. After raising the cathode potential from -0.42 to $-0.44 \mathrm{~V}$, at $232 \mathrm{~h}$ of electrolysis, tritium production re-commenced at $8.1 \times 10^{6} \mathrm{~T}_{\text {atoms s}}{ }^{-1} \mathrm{~cm}^{-2}$. Thus, an incubation period is needed after the reaction is quenched. The reaction was quenched for the second time (at $406 \mathrm{~h}$ ), when $30 \mathrm{ml} \mathrm{D}_{2} \mathrm{O}$ was added. The decrease in $\mathrm{T}$ activity after $\mathrm{D}_{2} \mathrm{O}$ addition is due to the dilution. An incubation period of $65 \mathrm{~h}$ was needed for the reaction to restart again (at 471 h). No potential triggering was applied this time.

Quenching of T production also occurs when a great deal of turbulence is introduced. ${ }^{10}$ 
Figure 7 shows the cathode potential as a function of time and current density. Current transients observed after increasing the applied potential are shown in Fig. 8.

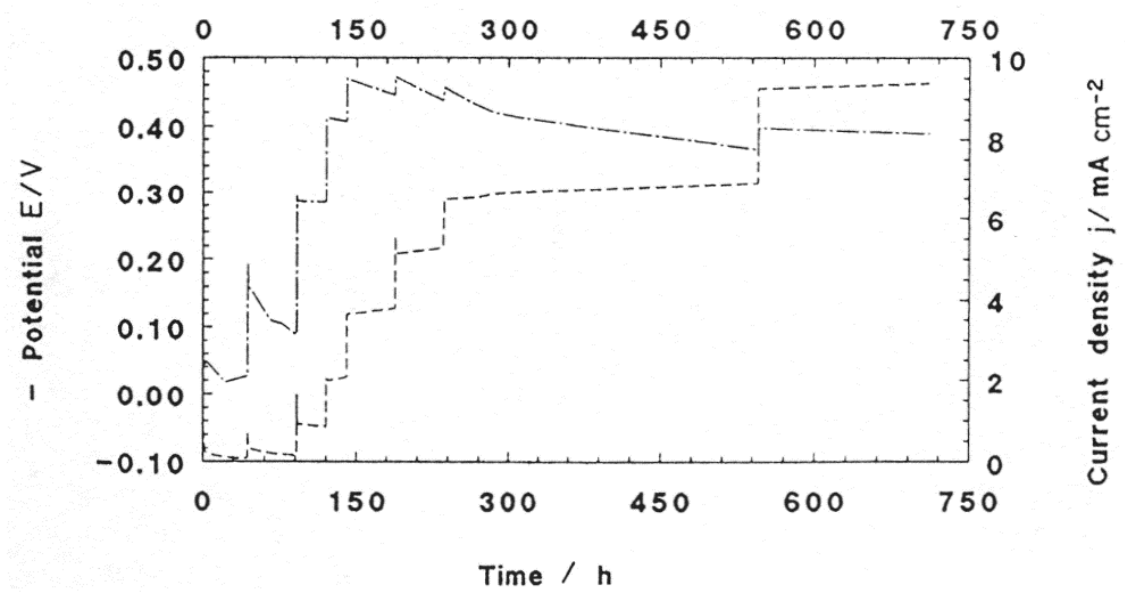

Fig. 7. Scheme of $\left(-^{\left.\cdot-{ }^{-}-\right)}\right.$the cathode potential changes, and (-------) corresponding current density transients during a complete run. 


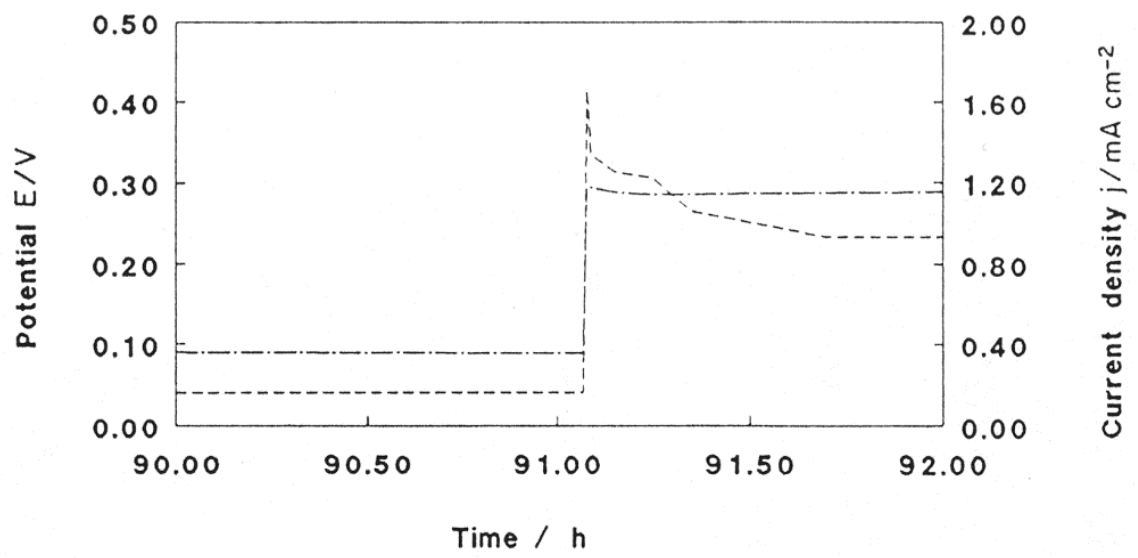

Fig. 8. (-- - --) Typical current transients observed when the applied potential $\left(-^{\left.--^{-}--^{-}\right)}\right.$) was decreased from -0.29 to $-0.38 \mathrm{~V}$.

Dependence of tritium production rate on electrode potential

After $36 \mathrm{~h}$ (Fig. 4), tritium production was triggered by the increase in applied electrode potential to -0.1 V vs. RHE (Fig. 7). From Figs. 5 and 6, four intervals of constant rate of tritium production may be recognized.

The relationship between $\log j$ and $\eta$, where 77 is the overpotential is shown in Fig. 9(a). The relation between overpotential and the rate of tritium production is given in Fig. 9(b). The value of the slope is $4.5 \mathrm{~V}^{-1}\left(\mathrm{~F} /\left(2 \times 2.3037^{*} 7^{\prime \prime}\right)-8.2 \mathrm{~V}^{-1}\right)$.

Fig. 9. (a) Current density, $\log j$, and (b) tritium production rate dependence on electrode
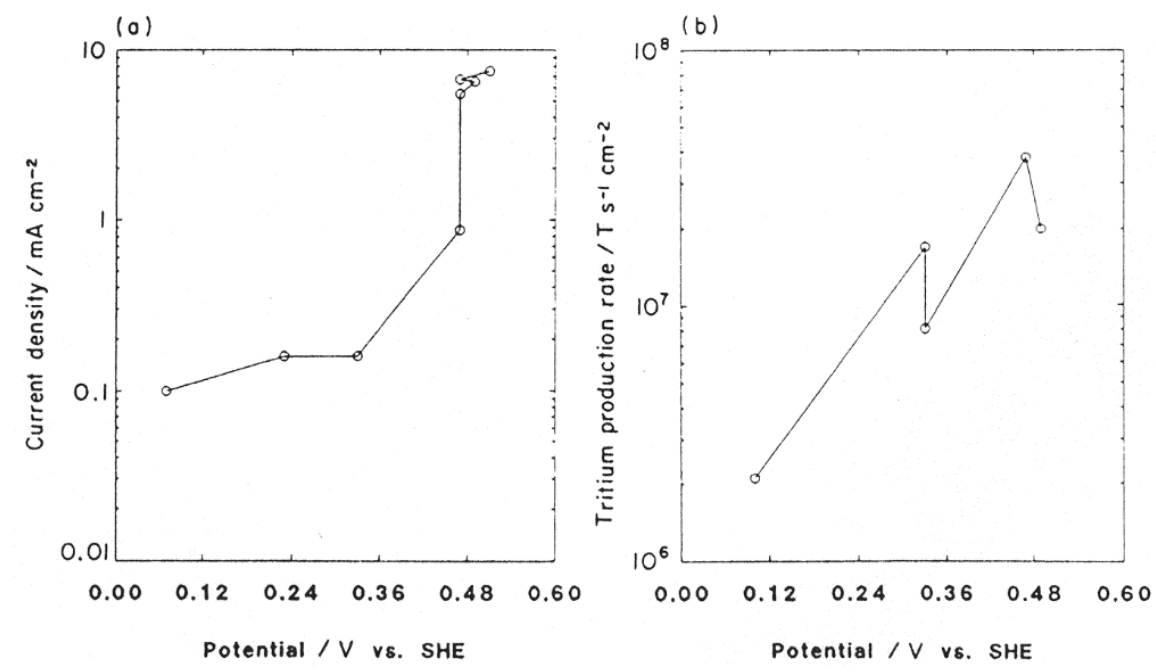

overpotential.

In the sense of a Tafel slope, then, the present result $=4 R T / F$.

Once the reaction is quenched by the addition of fresh $\mathrm{D}_{2} \mathrm{O}$, tritium production restarts after a change in potential (e.g. from -0.42 to -0.46 , at $232 \mathrm{~h}$, Fig. 4). However, a decrease of 
the potential too frequently (in time intervals of $\sim 30 \mathrm{~h}$, cf. 136 to $232 \mathrm{~h}$ ) did not seem to affect the reaction rate.

\section{Total amount of tritium produced}

The total tritium amount produced in the electrolyte after $761 \mathrm{~h}$ of electrolysis may be calculated:

$[\mathrm{T}]=204570 \mathrm{DPM} / \mathrm{ml}=2 \times 10^{5} \times 10^{7}=2 \times 10^{12} \mathrm{~T}$ atoms $/ \mathrm{ml}$

total in solution:

$[\mathrm{T}]=2 \times 10^{12} \times 80 \mathrm{ml}=1.6 \times 10^{14} \mathrm{~T}$ atoms

Tritium in the gas phase was not measured. There are several results published on the ratio of total tritium amounts measured in the gas phase and in the liquid. Ratios obtained were $\sim 4^{11}, 5-10^{12}, 3-4^{13}$, respectively. Taking the average ratio between tritium in the gas phase and in the liquid as 5 , one calculates that the total tritium produced is $10^{15}$ atoms.

\section{Tritium contamination from the laboratory air}

A study of contamination of the cells from the environment was performed by determination of the tritium picked up by an open non-working cell of the same design, placed next to the working cells. No tritium enhancement above the background value in this control cell was found in $250 \mathrm{~h}$. Another cell, A, of the same design was run in parallel to cell B (which showed positive tritium results), but did not show tritium production (Fig. 4).

\section{Tritium contamination of virgin Pd material}

Virgin Pd was dissolved in aqua regia and liquid scintillation analysis made upon distilled samples, by the method developed by Cedzynska and Will ${ }^{14}$. The closed apparatus for dissolution of Pd and distillation was similar to the one described in ref. 14. Several Pd discs were cut from the original $\mathrm{Pd}$ rod, at randomly chosen positions, and cut further into smaller samples (up to $300 \mathrm{mg}$ ). These were dissolved in aqua regia ( $\sim 2 \mathrm{ml}$ ), distilled and analyzed by liquid scintillation counting. No difference in tritium activity was observed when the distillate was neutralized by $\mathrm{NaOH}$. 
A summary of results is shown in Table 2. No tritium above background is found.

TABLE 2

Tritium analysis of the bulk of virgin Pd rod

\begin{tabular}{ll}
\hline Sample & $10^{8} \mathrm{~T}$ atoms $/ \mathrm{g} \mathrm{Pd}$ \\
\hline 1 & $4 \pm 3$ \\
2 & $3 \pm 3$ \\
3 & $4 \pm 3$ \\
\hline
\end{tabular}

Pd electrode examination after ceasing the electrolysis

Immediately upon ceasing electrolysis, the Pd electrode was quickly ( $1 \mathrm{~s}$ ) put into liquid $\mathrm{N}_{2}$. It was kept in liquid $\mathrm{N}_{2}$ for one week and then cut as described above.

Tests for tritium content in the bulk of Pd were performed in two ways. The first used the method by Cedzynska and Will ${ }^{14}$. The other used a long anodic treatment to expel tritium from the Pd electrode.

Pd was also analyzed for $\mathrm{He}^{3}$ and $\mathrm{He}^{4}$ content.

Tritium analysis in the bulk of Pd

Dissolution in aqua regia

Pd samples $(0.3 \mathrm{~g})$ were dissolved in aqua regia solution in a closed distillation system and the solvent distilled into a collection vessel. ${ }^{14}$ Samples of $0.5 \mathrm{ml}$ were taken for scintillation measurement. The following results were calculated: Pd sample, $0.286 \mathrm{~g}$; distillate volume, $1 \mathrm{ml}$; [T] measured $=101 \mathrm{DPM} / 0.5 \mathrm{ml}$; [T] in $\mathrm{Pd}=[(101-28) \times 2 \times$ $10^{7} \mathrm{~J} / 0.286=5.7 \times 10^{8} \mathrm{~T}$ atoms $/ \mathrm{g} \mathrm{Pd}$.

Result of anodic polarization of the cathode

A parallel procedure was used to treat another piece of Pd (approx. 4 g, see Fig. 2) as the anode to perform electrolytic dissolution of tritium into $0.1 \mathrm{M} \mathrm{LiOH}$ aqueous solution. The cell potential was maintained at $6 \mathrm{~V}$ for 3 days. The experiments were performed in a closed cell with a recombiner (Pt black on carbon) inside the cell to convert DT gas into liquid. The following result is obtained: the Pd sample $(4.2559 \mathrm{~g})$ was discharged anodically $(6 \mathrm{~V})$ for 3 days into $20 \mathrm{ml} \mathrm{LiOH}(0.1 \mathrm{M}$ solution); [T in $0.1 \mathrm{M} \mathrm{LiOH}$ background] $=28$ $\mathrm{DPM} / 0.5 \mathrm{ml} ;[\mathrm{T}]$ after anodic discharge $=113 \mathrm{DPM} / 0.5 \mathrm{ml}$; [T] in $\mathrm{Pd}=[(113-28) \times 20 / 0.5 \times$ $\left.10^{7}\right] / 4.2559=8 \times 10^{9} \mathrm{~T}$ atoms $/ \mathrm{g} \mathrm{Pd}$. The corresponding amount by the Cedzynska and Will approach would have been $5 \times 10^{9}$ atoms T/gram.

Quenching of $T$ production by $\mathrm{D}_{2} \mathrm{O}$ additions as a test for $T$ contamination of $\mathrm{Pd}$ 
On two occasions (Fig. 6) after addition of make up $\mathrm{D}_{2} \mathrm{O}$ T production was stopped for about two days. It is difficult to find any correlation between quenching of the reaction induced from the solution side and a possible source of $\mathrm{T}$ from spot contamination in the bulk of Pd. The same reasoning might be applied to quenching observed when a turbulence is introduced in the electrolyte [ID].

TABLE 3

Summary of tritium results

\begin{tabular}{|c|c|c|c|c|}
\hline $\begin{array}{l}\mathrm{T}_{\text {total }} \text { in } \\
\text { electrolyte }\end{array}$ & $\begin{array}{l}\mathrm{T} \text { in gas phase } \\
\text { (assuming } \\
\mathrm{T}_{\mathrm{g}} / \mathrm{T}_{\mathrm{l}}=5 \text { ) }\end{array}$ & $\begin{array}{l}\mathrm{T} \text { in } \mathrm{Pd} \text { (by } \\
\text { dissolution in } \\
\text { aqua regia }\end{array}$ & $\begin{array}{l}\mathrm{T} \text { in } \mathrm{Pd} \text { (by } \\
\text { anodic discharge } \\
\text { method) }\end{array}$ & $\begin{array}{l}\text { Total amount of } \\
\text { T produced } \\
\text { (electrolyte, gas, } \\
\text { bulk) }\end{array}$ \\
\hline $\begin{array}{l}1.6 \times 10^{14} \mathrm{~T} \\
\text { atoms } \\
\text { or } \\
1.5 \times 10^{13} \mathrm{~T} \\
\text { atoms } / \mathrm{g} \\
\text { or } \\
2.5 \times 10^{13} \mathrm{~T} \\
\text { atoms } / \mathrm{cm}^{2}\end{array}$ & $\begin{array}{l}8.1 \times 10^{14} \mathrm{~T} \\
\text { atoms } \\
\text { or } \\
5.4 \times 10^{13} \mathrm{~T} \\
\text { atoms } / \mathrm{g} \\
\text { or } \\
1.2 \times 10^{14} \mathrm{~T} \\
\text { atoms } / \mathrm{cm}^{2}\end{array}$ & $\begin{array}{l}5.1 \times 10^{9} \mathrm{~T} \\
\text { atoms } / \mathrm{g} \mathrm{Pd} \\
(\text { or total in } \\
\mathrm{Pd}=7.6 \times 10^{10} \\
\mathrm{~T} \text { atoms) }\end{array}$ & $\begin{array}{l}8 \times 10^{9} \mathrm{~T} \\
\text { atoms } / \mathrm{g} \mathrm{Pd} \\
\text { (or total in } \\
\mathrm{Pd}=1.2 \times 10^{11} \\
\mathrm{~T} \text { atoms) }\end{array}$ & $\begin{array}{l}\sim 10^{15} \mathrm{~T} \text { atoms } \\
\text { or } \\
6.9 \times 10^{13} \mathrm{~T} \\
\text { atoms } / \mathrm{g} \\
\text { or } \\
1.5 \times 10^{14} \mathrm{~T} \\
\text { atoms } / \mathrm{cm}^{2}\end{array}$ \\
\hline
\end{tabular}

Attempt to restart $T$ production after ceasing the electrolysis

A part of the electrode (Fig. 2) used as an anode to analyze $\mathrm{T}$ in the bulk of Pd. as described above, was then placed in a smaller closed cell containing 0.1 M LiOD. An attempt was made to restart the electrode as a $\mathrm{T}$ producer. However, no further $\mathrm{T}$ production was found.

Tritium results are summarized in Table 3.

The tritium content in Pd found by the two methods matched well $\left(5.1 \times 10^{9}\right.$ and 8.0 $\times 10^{9} \mathrm{~T}$ atoms g-1). These values are $\sim 10^{4}$ times below the tritium found in the electrolytic solution at the end of electrolysis (Table 3).

\section{Helium analysis}

\section{Helium analysis in the bulk of electrolyzed Pd samples which produced tritium}

After the electrolysis had been interrupted to analyze for other nuclear products in the bulk of the Pd electrode that produced tritium, the electrode was stored in liquid $\mathrm{N}_{2}$ and then sliced. Samples 5a-1 to 5a-4 (see Fig. 2) were not treated thermally, while samples 5b-1 to 5b-4 and $5 \mathrm{c}-1$ and $5 \mathrm{c}-2$ were degassed at $150^{\circ} \mathrm{C}$ for $24 \mathrm{~h}$. Samples $5 \mathrm{a}$ and $5 \mathrm{c}$ (outer slices) are those cut from the bottom of disc 5, having the largest area in contact with the solution during the electrolysis. In series 5b, only one side (inner slice) was exposed to the solution. Samples 5c 
were from another $90^{\circ}$ segment (outer slice). Thus, series $5 \mathrm{a}$ and $5 \mathrm{c}$ are from the near-surface region.

Presence of ${ }^{4} \mathrm{He}$

All samples, with ( $5 \mathrm{~b}$ and $5 \mathrm{c}$ ) and without (5a) thermal treatment showed positive findings of ${ }^{4} \mathrm{He}$. Background values were obtained by repeating the calibration procedure before each analysis using Rockwell control Pd specimens, free of He. ${ }^{8}$ To obtain the net helium released from each specimen, the ${ }^{4} \mathrm{He}$ values from the Rockwell control specimens were averaged separately, for each days' runs, and then these values were subtracted from the ${ }^{4} \mathrm{He}$ amounts released by each specimen giving the net helium release data in Table 4, Column 6. The data in Column 6 therefore represent the amounts of ${ }^{4} \mathrm{He}$ released by the specimens that exceeded the average amount released or desorbed during the analysis of the Rockwell control specimens. Results are summarized in Table 4. 
TABLE 4

Results of ${ }^{4} \mathrm{He}$ analysis in electrolyzed Pd samples that produced Tritium. Average background value: $0.5 \times 10^{9}{ }^{4} \mathrm{He}$ atoms

\begin{tabular}{|c|c|c|c|c|c|}
\hline \multicolumn{3}{|c|}{ Samples near the surface (outer slices) } & \multicolumn{3}{|c|}{ Samples away from the surface (inner slices) } \\
\hline Sample & $\begin{array}{l}\text { Sample mass }{ }^{\mathrm{a}} \\
/ \mathrm{mg}\end{array}$ & $\begin{array}{l}{ }^{4} \mathrm{He} / 10^{9} \\
\text { atoms or } \\
\left(10^{11}\right. \\
\text { atoms/g) }\end{array}$ & Sample & $\begin{array}{l}\text { Sample mass }{ }^{\mathrm{a}} \\
/ \mathrm{mg}\end{array}$ & $\begin{array}{l}{ }^{4} \mathrm{He} / 10^{9} \\
\text { atoms or } \\
\left(10^{11}\right. \\
\text { atoms/g) }\end{array}$ \\
\hline $5 a-1$ & 30.92 & $\begin{array}{l}3.8 \pm 0.3 \\
(1.2 \pm 0.1)\end{array}$ & $1 b-1$ & 27.79 & $\begin{array}{l}1.9 \pm 0.3 \\
(0.7 \pm 0.1)\end{array}$ \\
\hline $5 a-2$ & 39.70 & $\begin{array}{l}166.8 \pm 3.3 \\
(42 \pm 0.8)\end{array}$ & $1 b-2$ & 30.01 & $\begin{array}{l}2.5 \pm 0.3 \\
(0.8 \pm 0.1)\end{array}$ \\
\hline $5 a-3$ & 42.37 & $\begin{array}{l}3.4 \pm 0.3 \\
(0.8 \pm 0.1)\end{array}$ & $1 b-3$ & 23.85 & $\begin{array}{l}0.4 \pm 0.3 \\
(0.17 \pm 0.12)\end{array}$ \\
\hline $5 a-4$ & 20.22 & $\begin{array}{l}2.1 \pm 0.6 \\
(1.0 \pm 0.3)\end{array}$ & $1 b-4$ & 33.05 & $\begin{array}{l}1.7 \pm 0.6 \\
(0.5 \pm 0.2)\end{array}$ \\
\hline $5 c-1^{b}$ & 44.63 & $\begin{array}{l}1.9 \pm 0.5 \\
(0.4 \pm 0.1)\end{array}$ & & & \\
\hline $5 c-2^{b}$ & 30.40 & $\begin{array}{l}-0.1 \pm 0.5 \\
-0.03 \pm 0.1\end{array}$ & & & \\
\hline
\end{tabular}

${ }^{\text {a }}$ Mass uncertainty is $\pm 0.01 \mathrm{mg}$.

${ }^{\mathrm{b}}$ Samples of series $5 \mathrm{~b}$ and $5 \mathrm{c}$ were pretreated thermally $\left(150^{\circ}\right.$, C. 24 h. $<10^{4}$ Torr).

Excess ${ }^{4} \mathrm{He}$ was observed in 9 of the 10 electrolyzed palladium samples from electrodes which produced tritium. The amounts ranged from 0.4 to $166.8 \times 10^{9}$ atoms. The estimated analysis uncertainty averaged $-0.5 \pm 10^{9}$ atoms (except for the highest result, where the uncertainty is $\sim 2 \%$ ). No ${ }^{4} \mathrm{He}$ was observed (above background) in the non-electrolyzed (chemically pretreated) palladium (two slices from the same virgin Pd rod cut as in Fig. 2) or in the platinum anode material ${ }^{8}$.

Absence of ${ }^{3} \mathrm{He}$

Mass spectroscopy analysis for thermally non-treated series of samples 5a showed small amounts of mass number 3 species. Values obtained were within the range of 0 to $3.8 \times$ $10^{9}$ atoms per sample. The background value for ${ }^{3} \mathrm{He}$ ranged from 0.2 to $1.3 \times 10^{9}{ }^{3} \mathrm{He}$ atoms (per approx. $30 \mathrm{mg}$ of sample). Samples of series $5 \mathrm{~b}$ and $5 \mathrm{c}$ were then treated thermally at $150^{\circ} \mathrm{C}$ for $24 \mathrm{~h}$ in vacuum, in order to expel highly loaded hydrogen isotopes from the $\mathrm{Pd}$ bulk. After this pretreatment, mass spectrometry analysis was again performed. Analysis of all the samples in series $5 \mathrm{~b}$ and $5 \mathrm{c}$ now showed no isotopes of mass 3 . It was concluded that isotopes of mass 3 , found in samples $5 \mathrm{a}-1$ to $5 \mathrm{a}-4$, originated from HD species. This is 
highly probable, because NMR measurements showed up to $10 \%$ light water in the electrolyte at the end of electrolysis. It has been shown that protium, once entered into the electrolyte, will be concentrated further in the palladium during electrolysis ${ }^{15}$.

The total tritium found in the electrolyte, $\mathrm{N}_{0}=1.6 \times 10^{14} \mathrm{~T}$ atoms is given in Table 3 . Supposing this amount of $\mathrm{T}$ originated from contaminated $\mathrm{Pd}$, one calculates the amount of ${ }^{3} \mathrm{He}$ produced through the decay:

$\mathrm{T} \rightarrow{ }^{3} \mathrm{He}+\mathrm{e}^{-}$

Assuming an age of the Pd samples of only 6 months, a corresponding amount of ${ }^{3} \mathrm{He}$ produced and remaining in the $\mathrm{Pd}{ }^{16}$ will be:

Number of ${ }^{3} \mathrm{He}$ atoms $=\left(1-\mathrm{e}^{-\lambda t}\right) N_{0}=4.5 \times 10^{12}$

(where $\mathrm{A}$ is the decay constant in units of month $^{-1}$ )

It follows that the large amount of tritium found in the electrolyte was produced in or on the electrode and did not arise from contaminated palladium.

TABLE 5

Summary of EDS analysis

\begin{tabular}{llrrrrr}
\hline Sample & Spot & Pd/at.\% & Cu/at.\% & Zn/at.\% & Pt/at.\% & Si/at.\% \\
& position & & & & & \\
\hline "Hi tritium" & A & 1.2 & 93.0 & 0 & 5.8 & 0 \\
& B & 8.0 & 89.2 & 0 & 2.9 & 0 \\
& C & 90.7 & 7.3 & 0 & 1.6 & 0 \\
"No tritium" & A & & & & & \\
& B & 8.0 & 93.2 & 4.2 & 2.5 & 0 \\
& C & 37.4 & 8.7 & 5.0 & 1.6 & 0 \\
& D & 41.0 & 25.2 & 45.7 & 2.8 & 0 \\
"Pretreated" & A & & & & & \\
& B & 79.7 & 16.4 & 2.0 & 4.0 & 0 \\
& C & 79.8 & 9.2 & 0.6 & 0 & 1.9 \\
& D & 77.4 & 18.7 & 2.0 & 0 & 0.4 \\
"Untreated" & A & 98.8 & 1.0 & 0.0 & 0 & 0.3 \\
& B & 98.5 & 0.6 & 0.5 & 0 & 0.4 \\
\hline
\end{tabular}


Surface analysis

Results of XPS and EDS surface analyses

XPS and EDS analyses of the electrode surface were performed at several different spots. Table 5 summarizes the results of EDS analysis. The first analysis was accomplished on an untreated Pd electrode surface. The second was performed on the electrode pre-treated as described above. A third set of data, "no tritium", represents an electrode pretreated in a standard way, and which did not exhibit positive tritium findings after one month of electrolysis. The final, fourth, set of data was obtained on an electrode that had shown high levels of tritium production. Different spots analyzed have symbols A, B, C, etc.

The "untreated" sample shows a relatively impurity-free Pd surface. The amounts of $\mathrm{Cu}$ and/or $\mathrm{Zn}$ may be regarded as negligible. The other samples show spots of pure $\mathrm{Pd}$ (above $90 \%$ ) as well as spots contaminated by impurities, mainly $\mathrm{Cu}$, where the $\mathrm{Pd}$ concentration was as low as $4-7 \%$. In order to have this high concentration of $\mathrm{Cu}$ to a depth of $1 / \mu \mathrm{m}$ one calculates that there should be about $10^{5} \mathrm{~mol}$ of $\mathrm{Cu}$ in solution. Careful examination of the spots at the electrode surface close to the $\mathrm{Cu}$ contact (Fig. 2) shows very little $\mathrm{Cu}$ (see spot D for the "pretreated" sample in Table 5). Low amounts of Pt (up to 5\%) were found after electrolysis on the "no tritium" and "high tritium" samples.

Particularly careful examination of the surface of the electrode which showed a high level of tritium production ("high tritium") and one which was pretreated in the same way, but did not give positive tritium results ("no tritium"), was done. By scanning different spots at the surface and combining SEM and EDS analyses, significant differences were found between these two samples. A difference in morphology was present. Well defined crystal deposits were found in the case of the electrode which produced tritium (Fig. 10a). EDS analysis for the spots focused precisely in the region where these crystals were formed, see Table 5 ("high tritium" spot A and B (B being focused directly on the crystal form)). The impurities were $\mathrm{Cu}$, up to $92 \%$, and Pt. up to $6 \%$. High impurity spots found on the "no tritium" sample showed "ball"-shaped deposits on the surface (Fig. 10(b)). The impurity is again $\mathrm{Cu}, 93 \%$ (Table 5, "no tritium" sample, spot A). Here some Zn (4.2\%) was found (spot A). Zn concentrations up to $45 \%$ (spots B, C and D) were found, depending on where the analysis was focused at the surface. Pt concentrations were found at about the same level in both eases.

XPS and depth profile investigations of a pretreated sample (acid etched and stored for 2 weeks in distilled water) and a sample which had exhibited high levels of tritium are shown in Figs. 11(a) and 11(b), respectively. A thick layer (over $200 \mathrm{~nm}$ ) consisting mainly of C, Cu, $\mathrm{Zn}$ and $\mathrm{Si}$ was detected in both cases. Little Pd was found at the surface. Larger amounts of $\mathrm{C}$ were found on the electrolyzed sample. 

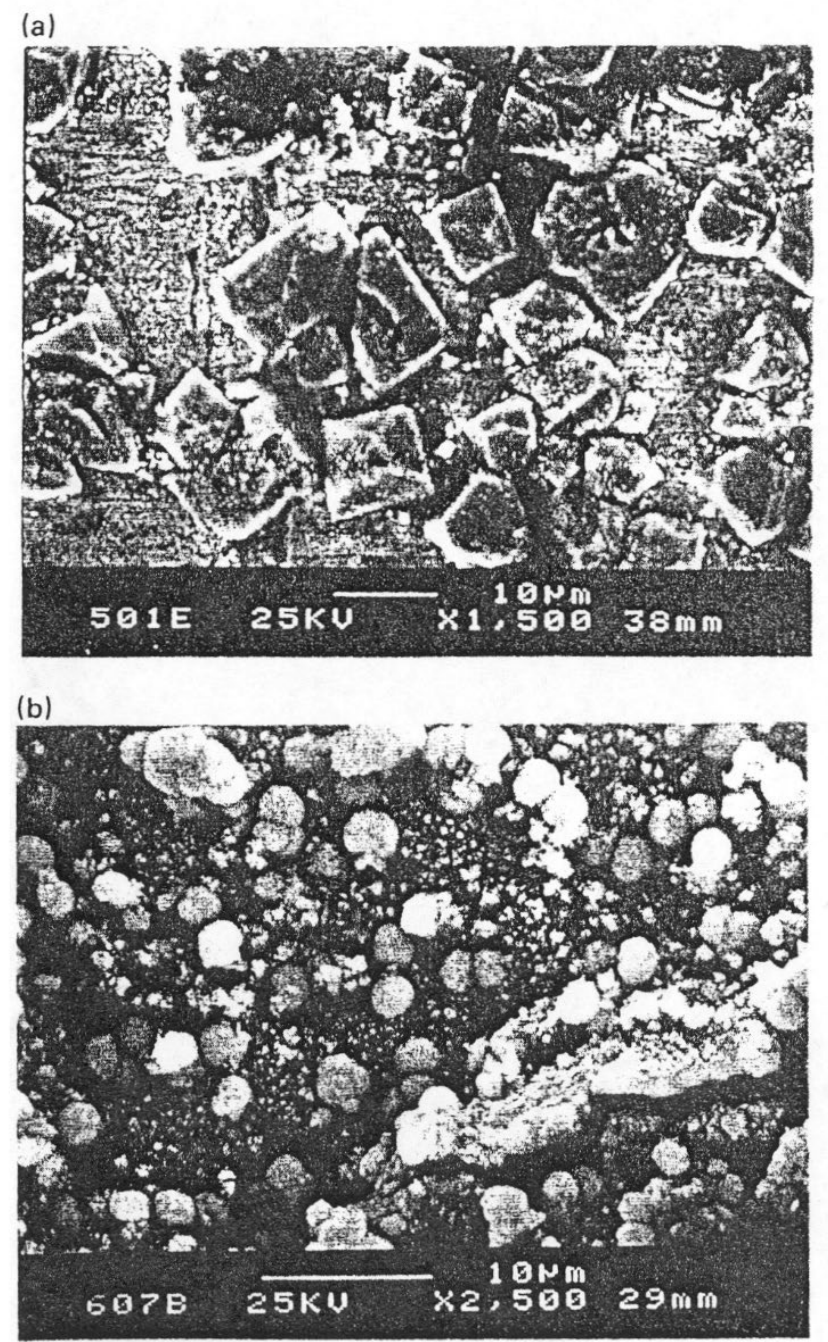

Fig. 10. SEM images of: (a) electrode which produced tritium: (h) "ball"-shaped deposits on the surface of an electrode that showed no tritium production 

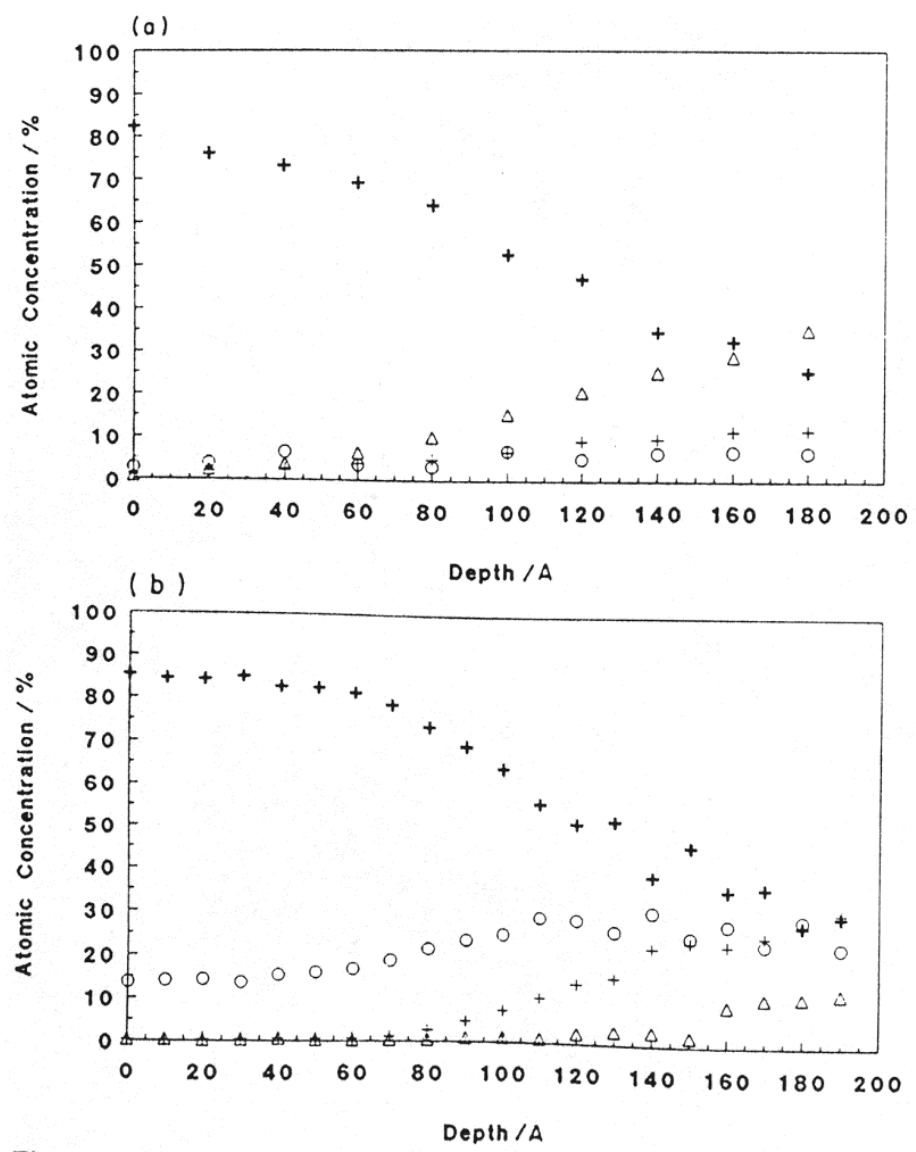

Fig. 11. XPS and depth profile investigations of: (a) pretreated sample (acid etched and stored for 2 weeks in distilled water) and (b) sample which exhibited high levels of tritium $(+) \operatorname{Pd}$ ' ( A ) $\mathrm{Cu} ;($ o) $\mathrm{Si}-(+) \mathrm{C}$.

\section{DISCUSSION}

\section{Contamination}

Precautions were taken to avoid contamination difficulties in the experiments. Four pieces of evidence attest to the absence of contamination.

(A) Three measurements of tritium in virgin pieces of the same kind of palladium as that which was used in the electrolysis experiment, applying a distillation technique ${ }^{14}$ to avoid the effect of particle size and color in the solution, showed no case in which the tritium content was above background.

(B) We had samples examined at a competent institution with respect to the presence in them of ${ }^{3} \mathrm{He}$ that would come from tritium decay and the ${ }^{3} \mathrm{He}$ measurements were not above background. No production of ${ }^{3} \mathrm{He}$ was evident, and 
therefore no earlier tritium contamination had occurred.

(C) Pickup from surroundings: the reported experiment on tritium pickup from the air of the laboratory was negative.

(D) After the electrode, work on which is reported here, was switched off, it could not be re-started. If the mounting tritium was coming from the surroundings (or from spot contamination in the electrode), turning the electrode on and off would hardly affect the exit of $\mathrm{T}$ into the solution.

\section{Electrochemical aspects of the processes concerned}

The recorded rates ${ }^{10,11,17}$ of T production vary from about $10^{4}-10^{10}$ atoms $\mathrm{cm}^{-2} \mathrm{~s}^{-1}$.

Trivial calculation shows that $10^{10}$ atoms cm-2 $\mathrm{s}^{-1}$ is equivalent to $10^{-9} \mathrm{~A} \mathrm{~cm}^{-2} \mathrm{~s}^{-1}$ and as the electrolysis is being carried out at a current density of about $20 \mathrm{~mA}$. the ratio of tritium to deuterium formation is about $10^{-7}$.

From Fig. 9(b) the Tafel slope is $4 R T / F$ (2.303), or about twice the normal Tafel slope for deuterium evolution. However, high Tafel slopes of this kind are often observed ${ }^{18}$.

The tritium production rate can be turned into a reaction rate and the irregularity of the points in Fig. 9(b) may be explained as partial current densities. The logarithmic dependence of the rate upon overpotential and the rational slope indicate that the rate determining step for the passage of tritium into solution is a charge transfer mechanism which probably involves a reverse proton discharge mechanism.

This is consistent with the considerable increases of the rate of production obtained by changing the potential and the roughly logarithmic dependence of heat production upon potential as observed by Fleischmann et al. ${ }^{19}$.

\section{Surface}

The appearance of the surface of the successful electrode was different from that of others that did not produce tritium. The successful electrode had a copper mosaic structure. The appearance of $\mathrm{Cu}$ is probably due to its corrosion during the storage procedure in distilled water.

\section{Effect of water upon the reactions}

Surprisingly, water did not affect the production of tritium up to a water content in the solution of $10 \%$. This is consistent with the high fugacity in voids theory (see below and refs. 18, 20 and 21) for if the part of the deuterium in the voids is protons and not deuterons it will surely make little difference when the amount is in the region of $10 \%$. On the other hand, 
in theories that depend upon adsorption of deuterium into the lattice, and binding of this deuterium to palladium atoms, $\mathrm{H}$ will always displace $\mathrm{D}$ and one would expect the water to diminish the tritium production ${ }^{22}$.

\section{Production of ${ }^{4} \mathrm{He}$}

${ }^{4} \mathrm{He}$ was found in spots, and these should surely be the cavities observed. The observed $23{ }^{4} \mathrm{He}$ was found in spots less than $1 \mathrm{~mm}$ from the surface (Table 4).

\section{Speculations on mechanism}

\section{Cavities}

The fact that a change of potential was found to trigger $\mathrm{T}$ production might be interpreted by the high fugacity theory ${ }^{18,20,21,24}$.

In order for the Griffith crack ${ }^{25}$ to spread it can be shown that:

$$
P_{D_{2}}=\left(\frac{16}{3} \frac{Y \gamma}{l}\right)^{1 / 2}
$$

where $Y$ is Young's modulus which for palladium is $1.17 \times 10^{-2} \mathrm{dyne}^{-2}$ and the surface tension, $\gamma$, is 1500 dyne $\mathrm{cm}^{-1}$. Taking the cavities as $10^{-5} \mathrm{~cm}$ the critical pressure after which the cavity expands (and fugacity falls) would be $3 \times 10^{4}$ atm. ${ }^{25}$

From the relation of fugacity of hydrogen in voids to the corresponding pressure, derived by Podgurski ${ }^{26,27}$, it follows that very high fugacities can be associated with relatively low pressure so that there is no contradiction in assuming that it is possible to obtain in the void space fugacities of $10^{17}$ atm, whilst the pressure (cf. eqn. 3) remains below that for cracking. As the cavities fill and attain the critical fugacity needed for fusion ${ }^{28}$, they also expand and therefore the fugacity falls and the critical condition is lost until a higher fugacity is tuned in by increasing the potential. This lasts for some time until the cavity again expands under this pressure, needing a further increase of potential, etc.

These calculations are inexact (assumption of Griffith type crack, etc.) and the very high fugacity $\left(\sim 10^{15} \mathrm{~atm}\right)$ which would correspond to a pressure in the crack is not far from that calculated by Lifshitz and Pitaevskii ${ }^{28}$ for the beginning of loss of charge on the particles of the plasma assumed to constitute the interior of the voids $\left(10^{17} \mathrm{~atm}\right)$.

There is evidence ${ }^{9}$ that the phenomena reported depend upon surface structure. Thus, the surface structure would determine the path and rate determining step of deuterium evolution and this in turn is known to determine the fugacity developed in voids (cf. Table 1 in ref. 29). Thus, the high fugacity in voids theory connects up the times of waiting for switch-on, the sporadicity of the results, and the fact that clean solutions do not give good results but dirty ones sometimes do ${ }^{30}$. Correspondingly, the observation of one of us (Chien ${ }^{10}$ ) that high turbulence causes a quenching of the production of tritium is consistent with this: the high 
turbulence would destroy the surface structure by knocking off promontories and this in turn may change the mechanism of deuterium evolution on the substrate.

\section{Effect of quenching}

Adding fresh $\mathrm{D}_{2} \mathrm{O}$ to the solution quenched the fusion reaction and it would not start again for some hours. It is possible that new $\mathrm{D}_{2} \mathrm{O}$ dissolves some of the impurity on some entities on the surface. But it may be that these surface components, which determine the mechanism of the hydrogen evolution reaction, consequently determine the dependence of fugacity in voids within the metal upon overpotential. Subsequently, it may be assumed that 'the desorbed entity re-adsorbs. Therefore, the mechanism which gave the high fugacity is reestablished and the tritium production begins anew.

\section{CONCLUSION}

It has been shown that at an electrode described in this paper, about $750 \mathrm{~h}$ of tritium production at about $10^{7}$ atoms $\mathrm{cm}^{-2} \mathrm{~s}^{-1}$ have taken place. After this time, the reaction was interrupted intentionally, and could not be re-started.

The facts reported are consistent with the achievement, as a result of a particular and specific configuration on the surface of the electrode, of a surface condition corresponding to high fugacity of $\mathrm{D}$, in voids within the electrode.

\section{ACKNOWLEDGMENTS}

The authors are particularly happy to acknowledge the financial support of EPRI under contract No. 2194A. The authors are also grateful for the help given them by Dr. Nathan Hoffman and his colleague, Dr. Bryan Oliver of Rockwell International, with respect to the analysis of helium in the electrodes. The authors are grateful for the help given by Miss A. Gonzalez-Martin in performing a part of the XPS analyses. The help of the Welch Foundation in supporting part of this work is gratefully acknowledged.

\section{REFERENCES}

1. M. Srinivasan, Current Sci. 60 (7) (1991) 417.

2. E. Storms, LAUR: 91-1493 Report.

3. J.O'M. Bockris and D. Hodko, Chem. Ind. 21 (1990) 688.

4. J.O’M. Bockris, G.H. Lin and N.J.C. Packham, Fusion Technol. 18 (1990) 11.

5. M. Fleischmann. Electrochem. News Lett. The Chemical Society, London, 71 (1.991) 1.

6. S. Strouer, Elecmat Co., personal communication.

7. H. Farrar IV and B.M. Oliver, J. Vac. Sci. Technol. A4, 1740 (1986).

8. B. Oliver et al., to be published.

9. N.J.C. Packham. K.L. Wolf. J.C. Wass, R.C. Kainthla and J.O’M. Bockris, J. Electroanal. Chem. 270 (1989) 451 .

N.C. Packham, Ph.D. Thesis. 1991, Texas A\&M University.

10. C.C. Chien and T.C. Huang. Proc. Anomalous Nuclear Effects in Deuterium/Systems, 22-24 Oct.1990, Provo, Utah. See also: C.C. Chien and T.C. Huang, J. Fusion Technol., in press.

11. G.H. Lin, R.C. Kainthla, N.J.C. Packham, O. Velev and J.O’M. Bockris. Int. J. Hydrogen Energy. 15 (1990) 
537.

12. S. Szpak and P. Mosier-Boss. J. Electroanal. Chem. 334 (1992) 111.

13. F. Will, K. Cedzynska and D.C. Linton, Investigation of Cold Fusion Phenomena in Deuterated Metals, Final Report, Technical Information Series PB91175885, Vol. 1, p. 1-131.

14. K. Cedzynska and F.G. Will, Investigation of Cold Fusion Phenomena in Deuterated Metals, Final Report, Technical Information Series PB91175885, Vol. 1, p. 1-80.

15. E. Storms and C. Talcott-Storms, Fusion Technol., 20 (1991) 246.

16. N. Hoffman, private communication.

17. D. Gozzi, P.L. Gignini, L. Petrucci, M. Tomellini, G. De Maria, S. Fullari. F. Garibaldi. F.Ghio and M. Jodice, II Nuovo Cimemo, 103A (1990) 143: Proc. Anomalous Nuclear Effects in Deuterium Solid Systems, 22-24 Oct. 1990, Provo, UT.

18. J.O'M. Bockris. D. Hodko and Z. Minevski, Proceedings of the II Annual Conference on Cold Fusion, 29 June4 July, 1991. Como, Italy, p. 337.

19. M. Fleischmann. S. Pons, M.W. Anderson. L. Jun Li and M. Hawkins. J. Electroanal. Chem.. 287(1990) 293.

20. J.O'M. Bockris. D. Hodko and Z. Minevski, presented al $180^{\text {th }}$ Meeting of The Electrochemical Soc. 13-18 Oct., 1991.

21. J.O’M. Bockris. C.C. Chien. D. Hodko and Z. Minevski, Int. J. Hydr. Energy, 17 (1992) 445.

22. M. Gittus and J.O’M. Bockris. Nature (London). May 11. 1989.

23. N. Hoffman and B. Oliver, private communication.

24. S. Szpak. private communication.

25. J.O’M. Bockris and A.K.N. Reddy. Modern Electrochemistry. $3^{\text {rd }}$ ed. Vol. 2. Plenum/Rosetta. 1979. p. 1340.

26. H. Podgurski. private communication. J.O’M. Bockris and P.K. Subrumanian. Electrochim. Ada. 16 (1971) 216.

27. C.E. Holley. W.J. Worlton and R.K. Zeigler. LA-2271 Report. Chemistry-General. T1D-4500. 14 ${ }^{\text {th }}$ edn. University of California. 195S.

28. E.M. LifshiU and L.P. Pitaevskii. Properties of Matter at very high Density in Statistical Physics.Part 1. $3^{\text {rd }}$ ed., Vol. 5. Pergamon Press. 1963. Chapter 11. p. 317.

29. J.O'M. Bockris and P.K. Subramanyan. Electrochim. Ada. 16(1971) 2169.

30. S. Jones. E.P. Palmer. J.B. Czirr. D.L. Decker, G.L. Jensen. J.M. Thome, S.F. Taylor and .1. Rafaelski. Nature (London). 338 (1989) 737.

See Also: Proceedings of the Anomalous Nuclear Effects in Deuterium/Solid Systems Conference. Brigham Young University. 22-24 Oct. 1990. 